\title{
Roman lead ingots from Macedonia-the Augustan shipwreck of Comacchio (prov. Ferrara, Italy) and the reinterpretation of its lead ingots' provenance deduced from lead isotope analysis
}

\author{
Michael Bode $^{1}$ (D) $\cdot$ Norbert Hanel $^{2,3} \cdot$ Peter Rothenhöfer $^{4}$
}

Received: 5 March 2021 / Accepted: 10 August 2021 / Published online: 15 September 2021

(c) The Author(s) 2021

\begin{abstract}
A shipwreck of the 3rd/2nd decade BC found near Comacchio (prov. Ferrara, Italy) in 1980 contained not only well-preserved technical equipment and commercial goods but also 102 Roman lead ingots. Since then, the origin of the ingots has been intensively discussed. Domergue et al. (2012) connected the epigraphic elements with lead isotope analyses and favored the southeastern Spanish lead ore mines being the source of the lead metal. An origin from the Balkan region (Illyricum) was favored by Dušanić (2008). Due to our investigations, both assumptions cannot be maintained. We present a new interpretation of the lead's isotope signature which best match data of ore deposits from Chalkidiki, Thasos island, and Pangaion mountains in the northern Aegean region.
\end{abstract}

Keywords Comacchio shipwreck $\cdot$ Roman lead ingots $\cdot$ Lead isotope analysis $\cdot$ Provenance study $\cdot$ Reinterpretation $\cdot$ Chalkidiki · Thasos · Pangaion

\section{Introduction}

In autumn 1980, the remains of a Roman cargo ship of the $3 \mathrm{rd} / 2$ nd decade $\mathrm{BC}$ came to light in the Valle Ponti lagoon northwest of Comacchio (pr. Ferrara, Italy) and about $20 \mathrm{~km}$ southwest of today's Po estuary (N 44.706, E 12.164) (Fig. 1). The ancient wreck was excavated by the Soprintendenza Archeologica dell'Emilia-Romagna between 1986 and 1989 (Berti 1990). In addition to the excellent preservation of the wreck with the ship's technical equipment and personal items of the crew or fellow travelers, the ship protrudes through a load of 102 lead ingots with a total weight of 3.1 tons and 28 trunks of boxwood. Other finds

Michael Bode

michael.bode@bergbaumuseum.de

1 Research Department, Deutsches Bergbau-Museum Bochum, Herner Straße 45, 44787 Bochum, Germany

2 Institut Für Archäologische Wissenschaften, Ruhr-Universität Bochum, Am Bergbaumuseum 31, 44791 Bochum, Germany

3 Archäologisches Institut, Universität zu Köln, Albertus-Magnus-Platz, 50923 Cologne, Germany

4 Department of History, Sun Yat-Sen University Zhuhai Campus, Xiangzhou District, Zhuhai 519000, Guangdong Province, People's Republic of China like amphorae cannot be clearly identified as cargo or onboard equipment (Parker 1992). Since the discovery of the Comacchio shipwreck, the ingots in particular have drawn interest. A controversial debate developed regarding their provenance (Illyricum or Hispania) and economic significance (Domergue 1987; Berti 1990; García-Bellido 1998a, b; Dušanić 2008; Domergue et al. 2012).

According to the more scientifically oriented readership of this journal, we decided to focus on the lead isotope investigation and interpretation but will also provide key information from epigraphy and archeology to support the analytical data-based conclusion. Full description of the ingots of Comacchio will be soon accessible in our monograph 'Corpus of Roman Lead Ingots' (hereinafter: CRLI) (see bibliography: Rothenhöfer et al. [forthcoming]).

\section{Roman lead ingots and their archeological value}

Why are Roman lead ingots so enlightening for the reconstruction of mining in Roman time? Antique texts give important, but often quite limited information. Archaeological traces of mining also rarely allow a deeper insight into the size, duration, and intensity of exploitation, especially since ancient mining places were often completely 


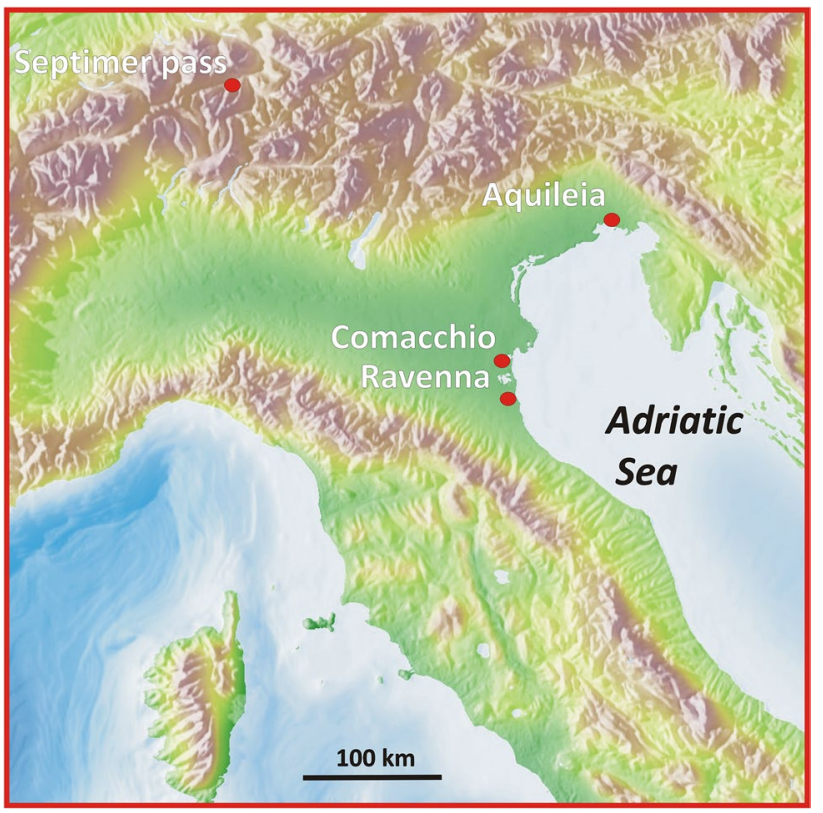

Fig. 1 Map showing the Italian mainland in the center with the find location of the Comacchio shipwreck (M. Bode)

destroyed by younger economic activities. On the other hand, mining products like lead ingots can contribute to a significant gain in knowledge as they often bear inscriptions, trademarks, and stamps referring to persons involved in mining and trade. In some cases, they even contain information about the origin of the metal (e.g., BRIT(annicum), GERMANICVM plumbum $=$ British or German lead) (see, e.g., Hanel and Rothenhöfer 2013). This information can be combined with archaeometallurgical data.

\section{Previous studies on the Comacchio ingots}

Domergue (1987) presented 99 of the 102 ingots. With the presentation of the types of ingots and epigraphic elements, he had already turned to questions about the historical and the economic significance of this shipload. With regard to the origin of the lead ingots, at that time C. Domergue ruled out a provenance from the Iberian Peninsula and rather considered a production within the Balkans. This first interpretation was carried out without the use of scientific analyses. In contrast to this, analytical investigations (mass spectrometric and neutron activation analyses), mentioned in a note in Berti (1990), led to the consideration of an origin from Spain.

In the 1990s, M.-P. García-Bellido proposed a military reading of several of the stamps which can be found on the ingots and connected them with production centers in the southwestern Extremadura of Spain (Baeturia: Azuaga and La Serena, prov. Badajoz) (García-Bellido 1995, 1998a, b, 2000). Both her interpretation of the stamps and the alleged provenance are untenable. For example, she connected the stamp MAC with the legio IV Macedonica (13 stamps on 12 ingots of type B5 and C3; see Figs. 2 and 3). That would be unique-at least on lead ingots. Much more plausible is the reading of MAC as a cognomen like Macer, Macedo, or Macrinus. As such it can be connected to the C. MATI-stamp (7 stamps on 4 ingots of type B5), both giving us the name of an entrepreneur, Gaius Mati(us?) Mac(er?). The use of two stamps to indicate the full name of an entrepreneur can also be observed on other lead ingots. As in the example of the abbreviation MAC, she also interprets the stamp GEME(...) (24 stamps on 18 ingots of type B5 and C3; see Figs. 2 and 4) as military. She refers here to the legio X gemina or gemella. The reading of the ingot stamps presented by García-Bellido was already rejected by Domergue et al. (2012).
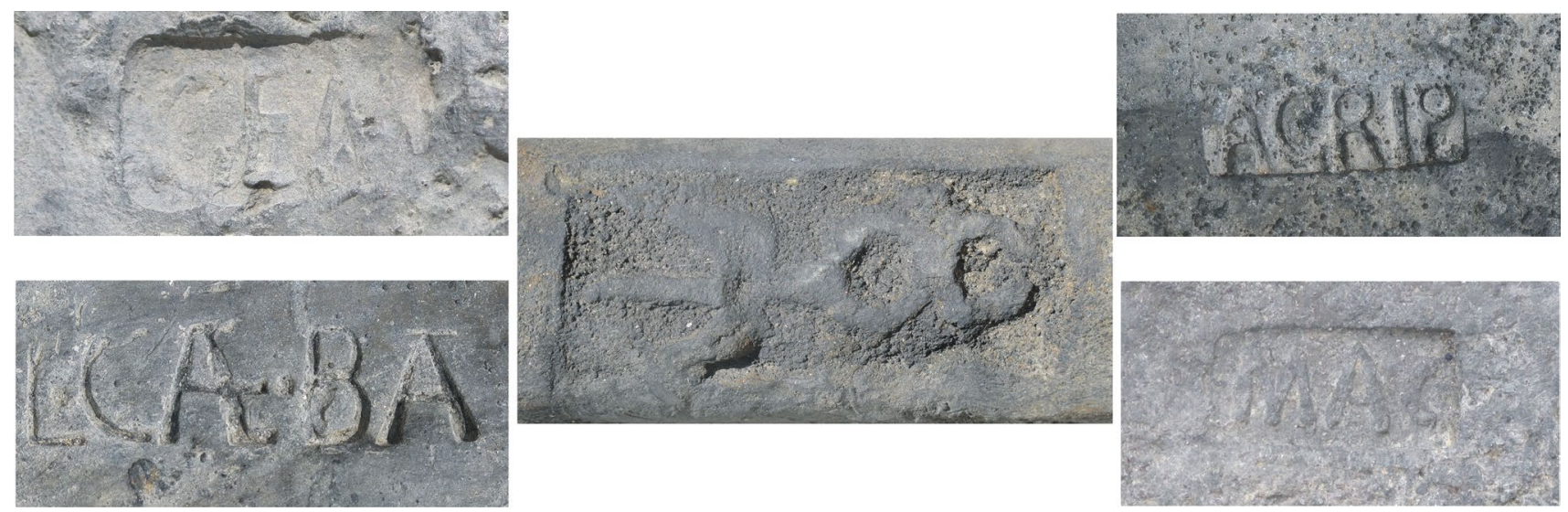

Fig. 2 Pictures of a caduceus symbol (center) as well as four different stamps, mentioned in the text: GEME(...) (top left), L(ucii) CAE(...) BAT(...) (bottom left), AGRIP (top right), MAC (bottom right) (N. Hanel) 
In 2008 S. Dušanić published new ideas about the origin of the lead cargo (Dušanić 2008). After a detailed analysis of the epigraphic elements, he advocated a provenance from Illyricum, even considering a production outside the borders of the empire by Illyrians in the Barbaricum. But the uniformity of the ingots and the use of cartouches with a caduceus motif, which is hardly to be expected in this way in the Barbaricum, in our view speak against this assumption. At the latest, the use of stamp inscriptions, which are predominantly to be interpreted as Latin name elements, must have taken place on Roman-controlled territory. As a suggestion for the origin of the ingots, he linked the Agrippa stamps with the rich silver-lead mountain areas in the vicinity of the Celtic (later Roman) city Sirmium (Sremska Mitrovica) in northwestern modern Serbia and constructed a connection to the (metalla or argentariae) Agrippi(a)na which Augustus in late 13 or $12 \mathrm{BC}$ should have bequeathed to Agrippa. Not only were these mines first mentioned much later at the end of the 3rd century AD (Codex Iustinianus 5.12.21), but also amongst other things the name of the locality Agrippina is less likely derived from Agrippa, but from Agrippina.

\section{Conclusions based on the epigraphical elements on the Comacchio ingots}

Generally, compared to other contemporary lead ingots, the cartouches and inscriptions on the lead load from Comacchio show striking differences. Noteworthy is the lack of molded inscriptions in cartouches on the top of the ingots (47 ingots of type A2 and B4 with molded inscriptions); almost all ingots from the mining areas around Carthago Nova were provided with this significant epigraphic element providing the names of the entrepreneurs. Instead of personal names, the caduceus - a widespread symbol of trade in Roman times - dominates in almost half of the lead ingots from Comacchio. The caduceus motif is already known on lead ingots from the 1st third of the 1st century $\mathrm{BC}$ from the mining area around Carthago Nova. However, the caduceus never appears alone on Hispanic lead ingots, but always in combination with the name of an entrepreneur. Regarding the Comacchio ingots, it can be noted that the caduceus motif is found in cartouches of ingots from different mining regions (compare Table 3).

The ingots also stand out due to their numerous stamps; 12 ingots are marked with 6 different stamp types. About two-thirds of the lead bears impressions of three to five different stamps. A clear sequence of the various stamps cannot be made out with certainty. Rather, they give the impression that they were stamped into the ingots more or less within a very short time and possibly even at the same place.
By far the most important epigraphic element is the AGRIP-stamp (Fig. 2), referring without doubt to Marcus Vipsanius Agrippa, the famous general, confidante, and son-in-law of Augustus and statesman (64/63-12 BC). The stamp AGRIP appears 189 times on 96 Comacchio ingots of all types. It can be ruled out that the AGRIP stamp is a control mark. In that case, Agrippa should have been involved in supervising the production of the Macedonian metalla and in controlling the distribution of the lead metal. So far there are no indications for this. If this were to be assumed, however, the L. CAE BAT stamp (Fig. 2), which can be found comparably frequently (120 times on 97 ingots) and is considered to name either a freedman or the son of a freedman of Caecilia Attica, the first wife of M. Agrippa or of his father-in-law Q. Caecilius Q. f. Pomponianus Atticus (Domergue 1987), would have to be interpreted in a similar way. But such a double control would be extremely unusual.

An interpretation as an owner's mark is much more convenient, also under the impression of a possible connection of L. Cae (...) Bat (...) to the familia of Caecilia Attica and thus to Agrippa. In this case, Agrippa and his wife would have bought lead (presumably via a freedman) from various mines in Macedonia and had it transported to northern Italy.

\section{Data collection for the provenance study}

In 2012, Domergue et al. published a detailed counter position to the previous formulated interpretations of the lead cargo of the Comacchio ship (see above). For this purpose, 20 of the 102 lead ingots were examined via lead isotope compositions. The authors distinguished two groups, the largest of which was assigned to the Cartagena-Mazarrón mining area or the Sierra Almagrera (pr. Almeria) and the small group with three ingots directly connected to the Cartagena-Mazarrón area (pr. Murcia).

In the following chapter, "The origin of the lead I (lead isotope analyis)," on the basis of these published and own lead isotope analyses (Table 3, Figs. 5 and 6), we will exclude the Spanish lead ores as a source of the Comacchio ingots and will favor instead the northern Aegean lead ore districts of the Chalkidiki, the island of Thasos, and the Pangaion mountains in Roman Macedonia (see map in Fig. 3).

\section{Ingot types and sampling strategy}

Four different types of ingots can be basically identified in the shipwreck (see Fig. 4 and Table 1). In the course of our workings on the CRLI monograph, we established a classification of ingots, to which we refer here. Type A2 has a rounded top which is somewhat flattened. The two narrow sides of the ingots are vertical or only slightly slanted. Type 
Fig. 3 The Serbo-Macedonian massif and Vardar Zone on the Chalkidiki peninsula, the Pangaion, and Lekanis mountains as part of the Greek Rhodopes as well as the island of Thasos (M. Bode)
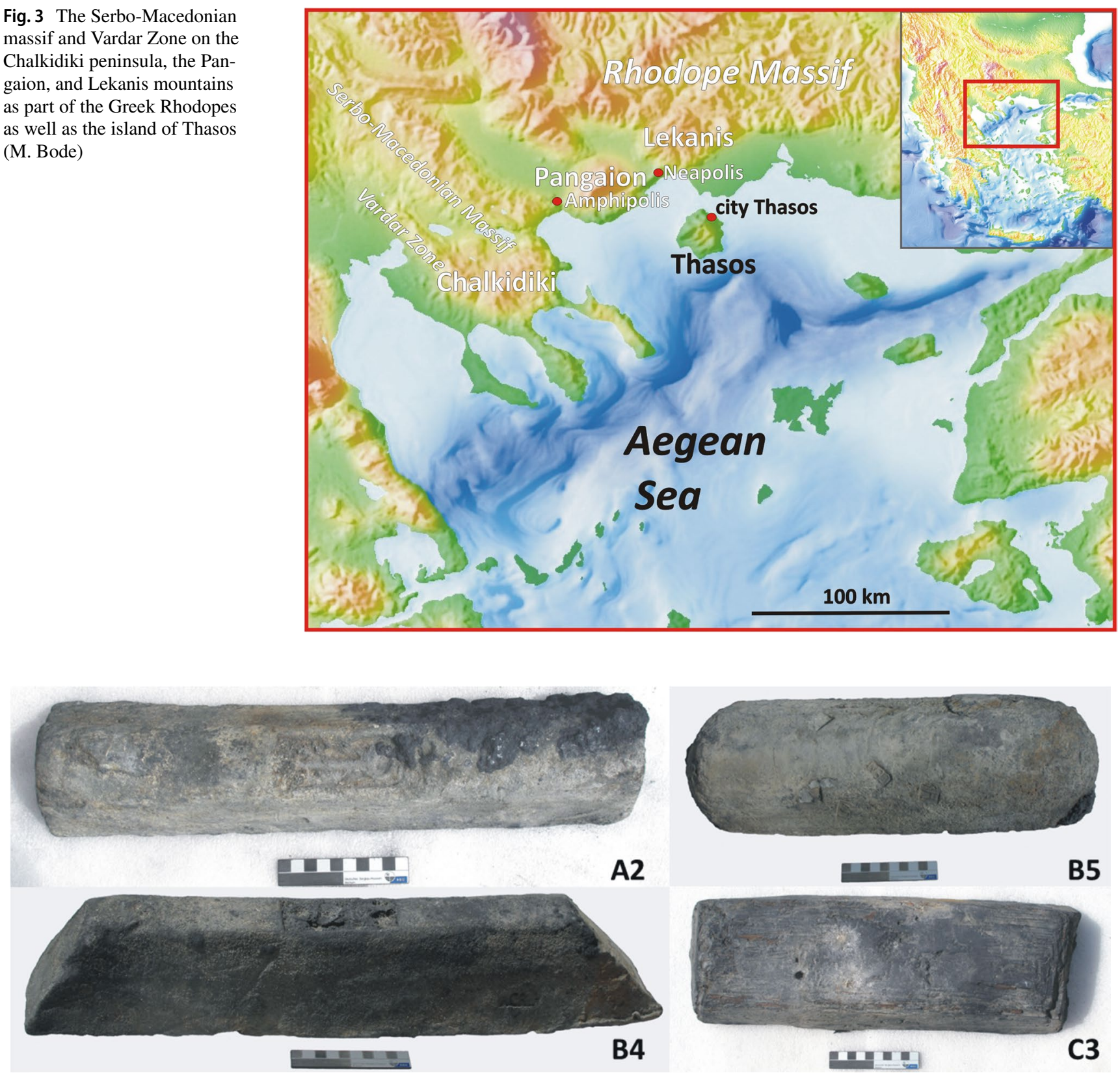

A2

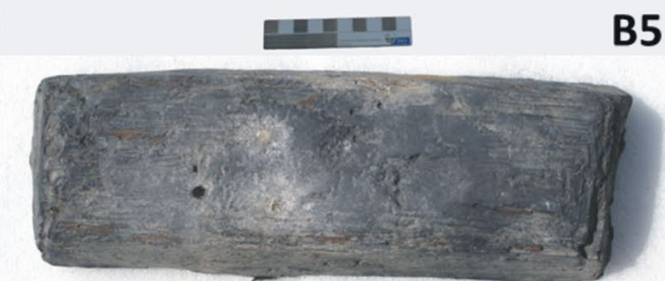

Fig. 4 Pictures of the ingot-types A2, B4, B5, and C3 from the shipwreck of Comacchio (N. Hanel)

B4 has a truncated and elongated pyramidal shape and strikingly flat-angled narrow sides. Type B5 resembles a loaf of bread, i.e., the top and the two narrow sides are more or less rounded. The shape of the ingots of type $\mathrm{C} 3$ is almost cuboidal or long rectangular with trapezoidal cross section, i.e., the top always has slightly shorter dimensions than the bottom of the ingot. During our investigation, almost exactly those ingots (5 of ingot-type A2, 3 of B4, 10 of B5, together 18 samples) were sampled in the same drill hole for a chemical analysis from which material had already been taken by the team around C. Domergue for lead isotope measurements.
Table 1 Type-classifications of the ingots of Comacchio according to their shapes

\begin{tabular}{lllll}
\hline Publication & Ingot type & Ingot type & Ingot type & Ingot type \\
\hline this study & A2 $(n=42)$ & B4 $(n=5)$ & B5 $(n=47)$ & C3 $(n=8)$ \\
$\begin{array}{l}\text { Domergue et al. } \\
(2012)\end{array}$ & Ser. IV & Ser. V & Ser. I-III & \\
$\begin{array}{l}\text { Domergue (1987) } \\
\text { Berti (1990) }\end{array}$ & Type IIIa & Type IIIb & Type I & Type II \\
\hline
\end{tabular}


Regrettably, we did not drill the ingots of type C3 for a laboratory test at that time. We conducted trace element analysis on all 18 samples, as well as lead isotope analysis on 12 of those samples (see Tables 2 and 3).

\section{Methodology}

The trace element analyses were carried out in the HfMA (House for Material and Analytics) of the Deutsches Bergbau-Museum Bochum with a HR-ICP-MS (high-resolutioninductively coupled plasma-mass spectrometer) (Element XR, Thermo Fisher Scientific). Before this for each sample, ca. $100 \mathrm{mg}$ of cleaned lead metal was dissolved in $5 \mathrm{ml}$ of concentrated $\mathrm{HNO}_{3}$ and $3 \mathrm{ml} \mathrm{H} \mathrm{O}_{\text {dest. }}$ and a $1000 \mathrm{mg} / \mathrm{l}$ stock solution prepared. They were diluted 1:10 for the trace element analysis with $5 \% \mathrm{HNO}_{3}$. The individual trace elements were quantified using an external calibration. The results were checked with lead standards PG 3 to 5 (Brammer Standard Company, Inc., Houston, USA) (results in Table 2).

The lead isotope analyses were performed in the Frankfurt Isotope and Element Research Center (FIERCE). For lead isotope determination with a MC-ICP-MS (multi collector-inductively coupled plasma-mass spectrometer) (Neptune Plus, Thermo Fisher Scientific), around 40 samples are usually measured automatically in a series. For this purpose, the dried-up lead eluate of each metal sample is diluted to about 125-ppb $\mathrm{Pb}$ with $2 \% \mathrm{HNO}_{3}$. A 10ppb concentrated Tl standard solution (NIST SRM-997) is then added for internal fractionation correction. The lead standard NIST SRM-981 is used as unknown sample to check the accuracy of the analysis results and the stability of laboratory and instrument conditions (mass drift) after every 5 samples (results in Table 3).

\section{The origin of lead I (lead isotope analysis)}

As mentioned before, according to the lead isotope comparison-in combination with epigraphic and historical considerations-Domergue et al. (2012) concluded that the lead ingot load should have been exported from southeastern Spain (Cartagena-Mazarrón, Sierra de Almagrera). This mineral-rich area, which was already exploited for lead in pre-Roman times and even more so also under Agrippa in the Roman period, is certainly a potential candidate like mining archaeology as well as several provenance studies on lead ingot complexes prove (compare, e.g., Ramallo Asensio 1985; Trincherini et al. 2009; Domergue et al. 2016; Baron et al. 2017; Bode et al. 2017; Rothenhöfer and Bode, 2018) . But the lead isotope diagrams in Fig. 5 clearly show that the Miocene lead ores from Murcia (Sierra de Cartagena, Sierra de Mazarrón) (black squares) and also from the neighboring province of Almería (Sierra de Almagrera, Sierra de Gador, Sierra de Alhamilla, Cabo de Gata) (white squares) do not come into question as they do not even overlap the ingot data clouds (black crosses) (ore geology and geologic-tectonical map of the Betic Cordillera; see Arribas and Tosdal 1994, Fig. 2, with listed locations). The same result could be obtained from a comparison with lead ore data from the old mines of the Balearic Islands or Catalonia, where no large-scale lead production in Roman times is evident (not shown) (compare data, e.g., from Canals and Cardellach
Table 2 Results of the trace element measurements for 18 lead ingots from Comacchio in wt.\%. Other elements such as $\mathrm{Ni}, \mathrm{Co}, \mathrm{Te}$, or $\mathrm{Se}$ occur in insignificant amounts or were below the limit of quantification

\begin{tabular}{lllllllll}
\hline Arch. inv. no & CRLI no & Ingot type & $\mathrm{Ag}$ & $\mathrm{As}$ & $\mathrm{Bi}$ & $\mathrm{Cu}$ & $\mathrm{Fe}$ & $\mathrm{Sb}$ \\
\hline 54,847 & 50 & $\mathrm{~A} 2$ & 0.016 & 0.080 & 0.006 & 0.09 & 0.001 & 0.10 \\
57,086 & 82 & $\mathrm{~B} 4$ & 0.020 & 0.042 & 0.007 & 0.10 & 0.001 & 0.23 \\
57,106 & 83 & $\mathrm{~B} 4$ & 0.017 & 0.038 & 0.081 & 0.11 & 0.049 & 0.18 \\
54,835 & 85 & $\mathrm{~B} 4$ & 0.007 & 0.110 & 0.075 & 0.39 & 0.001 & 0.26 \\
57,090 & 58 & $\mathrm{~A} 2$ & 0.017 & 0.003 & 0.006 & 0.56 & $<0.001$ & 0.02 \\
54,840 & 70 & A2 & 0.015 & 0.770 & 0.007 & 1.20 & 0.003 & 0.14 \\
57,088 & 71 & A2 & 0.015 & 0.270 & 0.009 & 0.18 & 0.001 & 0.13 \\
54,839 & 75 & A2 & 0.009 & 0.011 & 0.006 & 0.09 & 0.007 & 0.09 \\
54,859 & 88 & B5 & 0.002 & 0.006 & 0.003 & 0.47 & 0.001 & 0.06 \\
54,851 & 97 & B5 & 0.009 & 0.410 & 0.003 & 1.31 & 0.010 & 0.17 \\
54,854 & 98 & B5 & 0.005 & 0.490 & 0.002 & 0.94 & 0.002 & 0.14 \\
54,864 & 101 & B5 & 0.009 & 0.400 & 0.005 & 0.94 & 0.021 & 0.31 \\
54,869 & 112 & B5 & 0.013 & 0.004 & 0.006 & 0.12 & 0.005 & 0.02 \\
57,065 & 117 & B5 & 0.005 & 0.330 & 0.006 & 0.55 & 0.007 & 0.20 \\
57,126 & 123 & B5 & 0.002 & 0.730 & 0.003 & 1.37 & 0.004 & 0.24 \\
57,097 & 124 & B5 & 0.009 & 0.130 & 0.007 & 0.50 & 0.026 & 0.28 \\
57,093 & 128 & B5 & 0.015 & 0.170 & 0.007 & 0.36 & 0.003 & 0.26 \\
57,125 & 132 & B5 & 0.008 & 0.400 & 0.003 & 1.33 & 0.028 & 0.17 \\
\hline
\end{tabular}


Table 3 Lead isotope ratios of 20 lead ingots from Comacchio with suggested provenance. "Precision" of the published data in Domergue et al. (2012). Relative 2-sigma standard deviation of own values: ${ }^{206} \mathrm{~Pb} /{ }^{204} \mathrm{~Pb}=0.016$ to $0.11 \%,{ }^{207} \mathrm{~Pb} /{ }^{204} \mathrm{~Pb}=0.019$ to $0.11 \%,{ }^{208} \mathrm{~Pb} /{ }^{204} \mathrm{~Pb}=0.023$ to $0.11 \%,{ }^{208} \mathrm{~Pb} /{ }^{06} \mathrm{~Pb}=0.010$ to $0.014 \%$, ${ }^{207} \mathrm{~Pb} /{ }^{206} \mathrm{~Pb}=0.006$ to $0.014 \%$

\begin{tabular}{|c|c|c|c|c|c|c|c|c|c|}
\hline Arch. inv. no & CRLI no & Ingot type & ${ }^{208} \mathrm{~Pb} /{ }^{206} \mathrm{~Pb}$ & ${ }^{207} \mathrm{~Pb} /{ }^{206} \mathrm{~Pb}$ & ${ }^{206} \mathrm{~Pb} /{ }^{204} \mathrm{~Pb}$ & ${ }^{207} \mathrm{~Pb} /{ }^{204} \mathrm{~Pb}$ & ${ }^{208} \mathrm{~Pb} /{ }^{204} \mathrm{~Pb}$ & $\begin{array}{l}\text { Suggested prov- } \\
\text { enance }\end{array}$ & Data source \\
\hline 57,097 & 124 & B5 & 2.076 & 0.8381 & 18.692 & 15.665 & 38.802 & Pangaion & $\begin{array}{l}\text { Domergue et al. } \\
2012\end{array}$ \\
\hline 57,122 & 43 & A2 & 2.074 & 0.8380 & 18.678 & 15.653 & 38.739 & Pangaion & $\begin{array}{l}\text { Domergue et al. } \\
2012\end{array}$ \\
\hline 54,847 & 50 & A2 & 2.075 & 0.8385 & 18.700 & 15.679 & 38.805 & Pangaion & CRLI \\
\hline 57,106 & 83 & B4 & 2.068 & 0.8332 & 18.804 & 15.668 & 38.895 & Chalkidiki/Thasos & CRLI \\
\hline 54,834 & 84 & B4 & 2.066 & 0.8326 & 18.779 & 15.635 & 38.805 & Chalkidiki/Thasos & $\begin{array}{l}\text { Domergue et al. } \\
2012\end{array}$ \\
\hline 54,835 & 85 & B4 & 2.066 & 0.8327 & 18.787 & 15.644 & 38.822 & Chalkidiki/Thasos & $\begin{array}{l}\text { Domergue et al. } \\
2012\end{array}$ \\
\hline 57,090 & 58 & A2 & 2.073 & 0.8379 & 18.691 & 15.662 & 38.746 & Pangaion & $\begin{array}{l}\text { Domergue et al. } \\
2012\end{array}$ \\
\hline 57,132 & 63 & $\mathrm{~A} 2$ & 2.074 & 0.8380 & 18.683 & 15.657 & 38.742 & Pangaion & $\begin{array}{l}\text { Domergue et al. } \\
2012\end{array}$ \\
\hline 54,840 & 70 & A2 & 2.075 & 0.8384 & 18.674 & 15.657 & 38.740 & Pangaion & $\begin{array}{l}\text { Domergue et al. } \\
2012\end{array}$ \\
\hline 57,088 & 71 & A2 & 2.074 & 0.8382 & 18.675 & 15.653 & 38.730 & Pangaion & CRLI \\
\hline 54,839 & 75 & A2 & 2.075 & 0.8383 & 18.703 & 15.679 & 38.815 & Pangaion & CRLI \\
\hline 54,859 & 88 & B5 & 2.075 & 0.8386 & 18.697 & 15.680 & 38.804 & Pangaion & CRLI \\
\hline 54,851 & 97 & B5 & 2.076 & 0.8385 & 18.701 & 15.680 & 38.816 & Pangaion & CRLI \\
\hline 54,854 & 98 & B5 & 2.075 & 0.8386 & 18.697 & 15.679 & 38.803 & Pangaion & CRLI \\
\hline 54,864 & 101 & B5 & 2.076 & 0.8386 & 18.695 & 15.679 & 38.811 & Pangaion & CRLI \\
\hline 54,869 & 112 & B5 & 2.076 & 0.8382 & 18.705 & 15.679 & 38.829 & Pangaion & $\begin{array}{l}\text { Domergue et al. } \\
2012\end{array}$ \\
\hline 57,065 & 117 & B5 & 2.076 & 0.8385 & 18.696 & 15.677 & 38.810 & Pangaion & CRLI \\
\hline 57,126 & 123 & B5 & 2.076 & 0.8385 & 18.699 & 15.679 & 38.812 & Pangaion & CRLI \\
\hline 57,093 & 128 & B5 & 2.076 & 0.8386 & 18.696 & 15.678 & 38.813 & Pangaion & CRLI \\
\hline 57,125 & 132 & B5 & 2.076 & 0.8384 & 18.699 & 15.679 & 38.812 & Pangaion & CRLI \\
\hline
\end{tabular}

1997; Montero-Ruiz et al. 2009; Rafael et al. 2010; Hunt Ortiz et al. 2014).

And even without already isotopically excluding the ancient lead ore mines in the Betic Cordillera of Iberia, the find spot of the shipwreck on the west coast of the Adriatic Sea alone, away from the usual transport routes in the western Mediterranean region (e.g., Herschend 1995; Domergue et al. 2016), justify an equally critical lead isotope comparison with the ancient lead mines further to the East. Those deposits bear mineralization likewise geologically young and thus lead isotopically similar composed like those in the Andalusian fold mountains in the West of the Mediterranean (compare e.g. Arribas and Tosdal 1994, Fig. 1).

Lead ore deposits in the Aegean region (Greece, NW Turkey, Cyprus), which form together with other polymetallic ores the so-called Aegean field in a lead isotope diagram (compare Pernicka et al. 1984; Gale and Stos-Gale 1992), and the Roman lead ore deposits of the Danube region here certainly come into question. Although Roman mining, or at least its extent, has not been proven for the ancient deposits of the North Aegean, especially the Greek ancient mines of Laurion (Megala Pefka, Plaka, Kamresa, etc.), the Chalkidiki peninsula (Mavres Petres, Madem Lakkos, Olympias etc.), the Pangaion mountains (Nikisiani), and the offshore island of Thasos (Vouves, Marlou, Koumaria, etc.) with their available data have been shortlisted for the provenance study, furthermore the relatively nearby Roman mining areas of Serbia and the Kosovo (Šumadija, Kopaonik district). Lead isotope data also brought the ancient lead ore deposit of Tirebolu in northeastern Turkey into focus (about the deposits and ancient mining activities, see e. g. Unger and Schütz 1980; Wagner et al. 1986; Pernicka 1987; Chalkias et al. 1988; Gialoglou et al. 1988; Hauptmann et al. 1988; Meier 1995; Sayre et al. 2001; Wagner et al. 2003; Westner 2017).

Figure 6 , in which the published data of these old lead production areas were brought together, shows a clear connection of the Comacchio ingots (black crosses) to the 


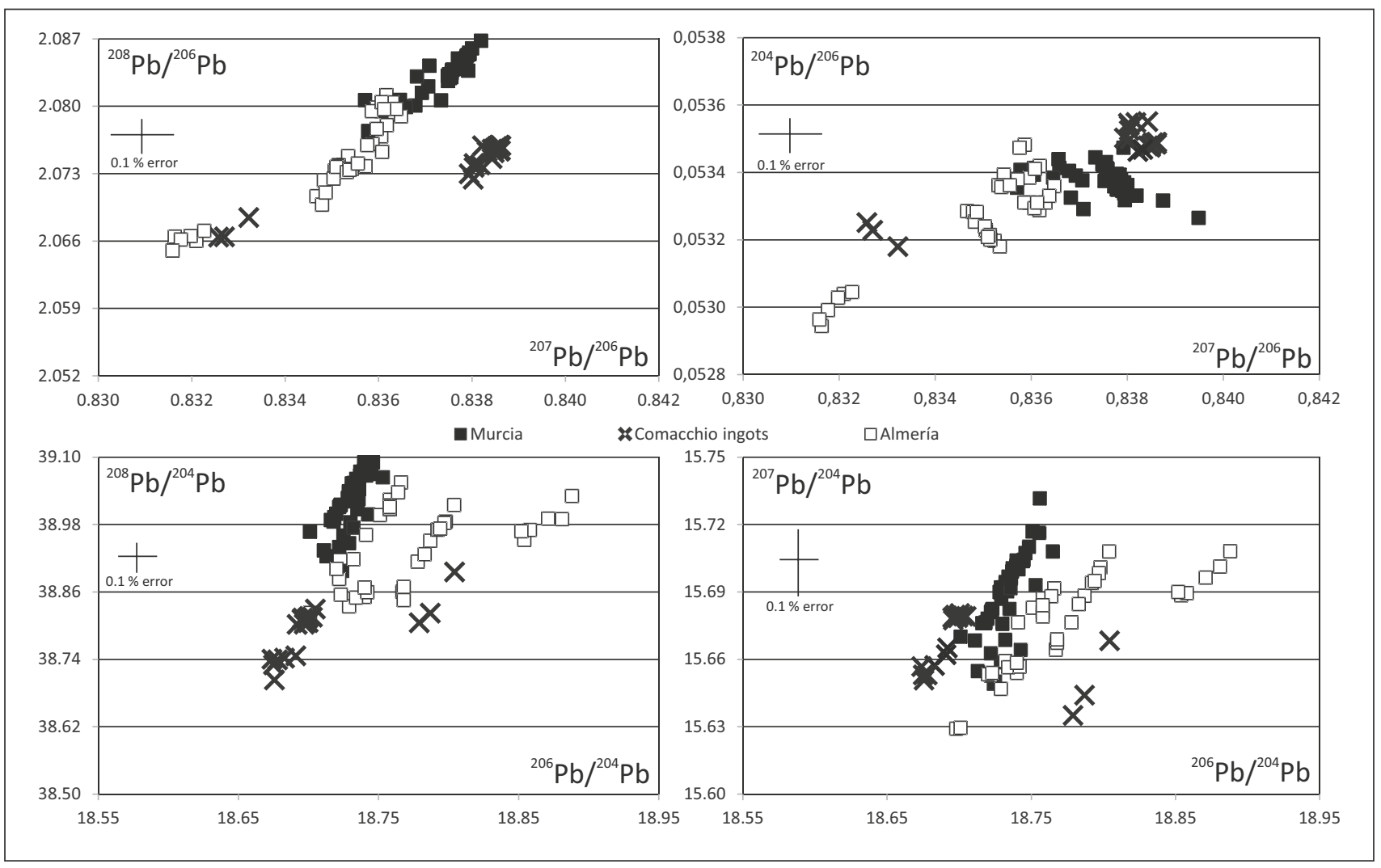

Fig. 5 Lead isotope ratio diagram-versions with data of lead mineralization from the provinces of Murcia (black boxes) and Almería (white boxes) in southeastern Spain as well as from 20 lead ingots from the Comacchio shipwreck (black crosses). According to the information provided by the ISOTRACE laboratory in Oxford, the error crosses (external reproducibility) refer to data generated with

lead mineralizations of the Pangaion (grey cycles) and the Chalkidiki ore deposits (grey diamonds), whereby in the latter case the ores of Thasos (white boxes) due to a few data outliers cannot be excluded. The Laurion (black squares) and the Serbo-Kosovar (white triangles) deposits are out of question. Interestingly, the ingot symbols form two narrow groups, the smaller one just made of B4 ingot types, coinciding with the data clusters of the Chalkidiki and partly of the island of Thasos, the bigger one with A2 and B5 types, falling into the Pangaion data field. A recent publication could also address fragments of a silver box from Mtskheta, Dedoplis Gora (Kareli district, Georgia) of the 1st century AD to the Pangaion ores (Parjanadze and Bode 2017). This is interesting, because the kingdom of Kartli was strongly politically influenced by Rome at that time.

Although further $1500 \mathrm{~km}$ distant from Comacchio than the island of Thasos or the Pangaion mountains, the ancient copper-lead mining area of Tirebolu-Esbiye, approx. $30 \mathrm{~km}$ east of Giresun on the Black Sea coast of northeastern Turkey, cannot be excluded clearly as a source for the ingots of type A2 and B5, which made up the largest part of the ingot a thermion mass spectrometer (TIMS) (all data without Müller et al. 2014; Baron et al. 2017; this study) (Dayton and Dayton 1986; Domergue et al. 2012; Arribas and Tosdal 1994; Stos-Gale et al. 1995; Trincherini et al. 2001; Müller et al. 2014; Baron et al. 2017; this study) (M. Bode)

load. Not just its lead isotope signatures (white diamonds) (Sayre et al. 2001; Wagner et al. 2003), also mining archaeological information should not be passed over. At Tirebolu, ca. 50 pinges evidently show ore exploitation in ancient times. And, in slag heaps, dated by ceramic finds from the Hellenistic-Roman period, remnants of litharge were found, testifying lead-silver extraction at that time (Seeliger et al. 1985). Nevertheless, at the current state of research, it seems rather less likely that lead was transported from outside of the Roman Empire on such a long waterway through the Black Sea and the Bosporus.

To conclude, Fig. 6 allows the hypothesis that there are two relatively distinct lead mining centers in the Aegean producing metal at the same time, with the Pangaion ore deposits, according to the ratio of 89:5 for the different ingot type groups, apparently exporting in greater amounts.

The Pangaion is a relatively small mountain range running from southwest to northeast in northern Greece (Davies 1935/1979; Unger 1987; Meier 1995). The length is $25 \mathrm{~km}$, its width $15 \mathrm{~km}$. Exploitation of gold- and silver-bearing ores could be proven, whereby silver rather was a by-product of 


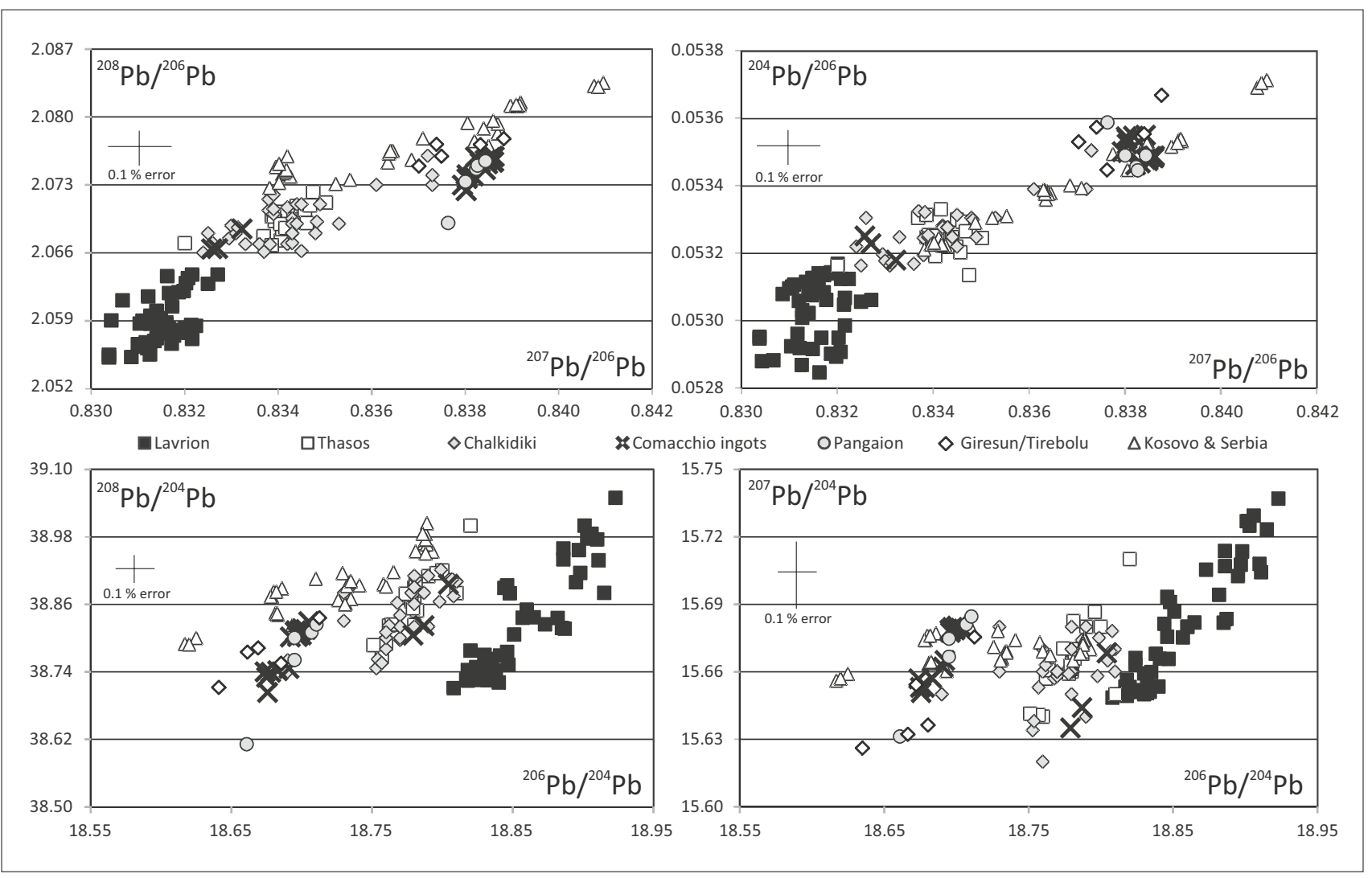

Fig. 6 Lead isotope ratio diagram-versions with data of lead mineralization from Laurion (black boxes), the Chalkidiki peninsula (grey diamonds), the island Thasos (white boxes), and the Pangaion mountains within modern Greece (grey cycles) as well as from Serbia and Kosovo (white triangles), the ore deposits of Giresun/Tirebolu in modern Turkey (white diamonds), and from 20 lead ingots from the Comacchio shipwreck (black crosses). According to the information provided by the ISOTRACE laboratory in Oxford, the error

lead cupellation. The knowledge about the exploitation in antiquity is still fragmentary; previous investigations suggest overall mining activities from the end of the Neolithic to the Byzantine period (Unger and Schütz 1980, 1982; Unger 1981, 1987). The ancient mining area of the Chalkidiki is located in the northeast of the peninsula, with the most important leadsilver mines on the north and south flanks of the Stratonikon mountains. Galena shows relatively high Ag contents $(0.21$ wt.\%). Ottoman and recent mining vastly destroyed the traces of antique activities; the roots of mining very likely go back to the Bronze Age (Davies 1935/1979; Wagner et al. 1986; Meier 1995). On Thasos the lead-silver mines are located on the western half of the island. The lead ores occur as galena and cerussite. The silver content is quite high in places $(0.15$ wt.\%). There is evidence that mining lasted from the early Iron Age to the Byzantine era. Thasian coins minted with local silver are present until the first century BC. To our knowledge, no Roman lead ingot that could be assigned to the island of Thasos, the Pangaion, or the Chalkidiki have yet been identified. bars (external reproducibility) refer to data generated with a thermion mass spectrometer (TIMS) (all data without Westner 2017; this study) (Domergue et al. 2012; Gale 1980; Vavelidis et al. 1985; Wagner et al. 1986; Chalkias et al. 1988; Gale et al. 1988; Pernicka et al. 1993; Stos-Gale et al. 1996; Sayre et al. 2001; Wagner et al. 2003; Veselinovíc-Williams 2011; Westner 2017; OXALID (n.d.); this study) (M. Bode)

Contrary to a very recent provenance study of Punic to Roman Republic silver coins treating lead isotope analyses and geological parameters statistically (Albarede et al. 2020), we present conventional 1:1 lead isotope data comparisons. Although the quality of TIMS-lead isotope data is not as good as MC-ICPMS lead isotope data, the combination of both data sets in this case study is sufficient to highlight the potential lead metal sources (Chalkidiki, Pangaion, Thasos) while safely excluding others in the region (e.g., Laurion, SerbiaKosovo). It should also not be forgotten that Roman lead ingots are a very special group of objects which, in addition to their unmixed lead from a single source, can also hold other important information about their origin, especially through epigraphic elements. Nevertheless, one should generally not exclude neighboring deposits for which lead isotope investigations have not yet been carried out, but which were certainly known in ancient times for their metal richness-for example, those in the Lekanis mountains east of the Pangaion (see descriptions of the ore deposits in Vavelidis et al. 1996, 1997). 


\section{The origin of lead II (trace element comparison)}

With regard to the lead's trace element pattern, concerning the B4 ingot group-even, (according to the relatively low $\mathrm{Ag}$ values) the lead might have been desilvered and the trace pattern noticeably changed (compare Pernicka and Bachmann 1983) — it seems reasonable to favor the Chalkidiki peninsula instead of the Thasos island as the more likely source of supply, since two samples (CRLI 83, 85) have significantly high Bi values like described by Wagner et al. (1986) for the lead mineralization there (Fig. 7) (it should be noted here that there is no lead isotope measurement for the ingot CRLI 82 with the low $\mathrm{Bi}$ values and its origin must remain open).

\section{The presumed transport route}

The route by which the lead ingots were transported from the deposits in Macedonia to the accident site of the ship cannot be determined with certainty. Because of the cheaper and faster sea transport compared to land transport, preference might have been given to shipping the lead ingots through the Aegean Sea (compare Drexhage et al. 2002).

In the case of the lead ingots coming from the Pangaion mountains, a relatively short land transport to a port can be assumed. The city of Amphipolis in the early principate would come into question; Amphipolis is now about $5 \mathrm{~km}$ from the sea coast at the Strymon River. Another way of shipping lead ingots from the Pangaion could have been to the east with the port of Neapolis (now Kavala). The linear distance from the mines in both cases is about $25 \mathrm{~km}$. For the island of Thasos, the city of the same name had important seaports from where the lead cargo could have been shipped away (Marc 2019). Which port in the Chalkidiki was considered for the export of the lead ingots cannot be clarified at the moment.

The further route of the lead freight from Macedonia must remain unknown, too, as well as the question at what point of the route the Comacchio ship took over its lead freight. In terms of its construction, the Comacchio ship is a flat-bottomed freighter (length $21.0 \mathrm{~m}$, width approx. $5.60 \mathrm{~m}$ ) primarily for inland, coastal, and lagoon voyages (e.g., Berti 1990).

\section{The destination of the lead cargo}

The destination of the (lead) cargo can only be defined vaguely. A use for Rome itself is to be ruled out, because in this case, the shipping route from the Ionian Sea through the Strait of Messina into the Tyrrhenian Sea would be much cheaper and more convenient. According to current knowledge, various scenarios for the destination are conceivable, but they remain

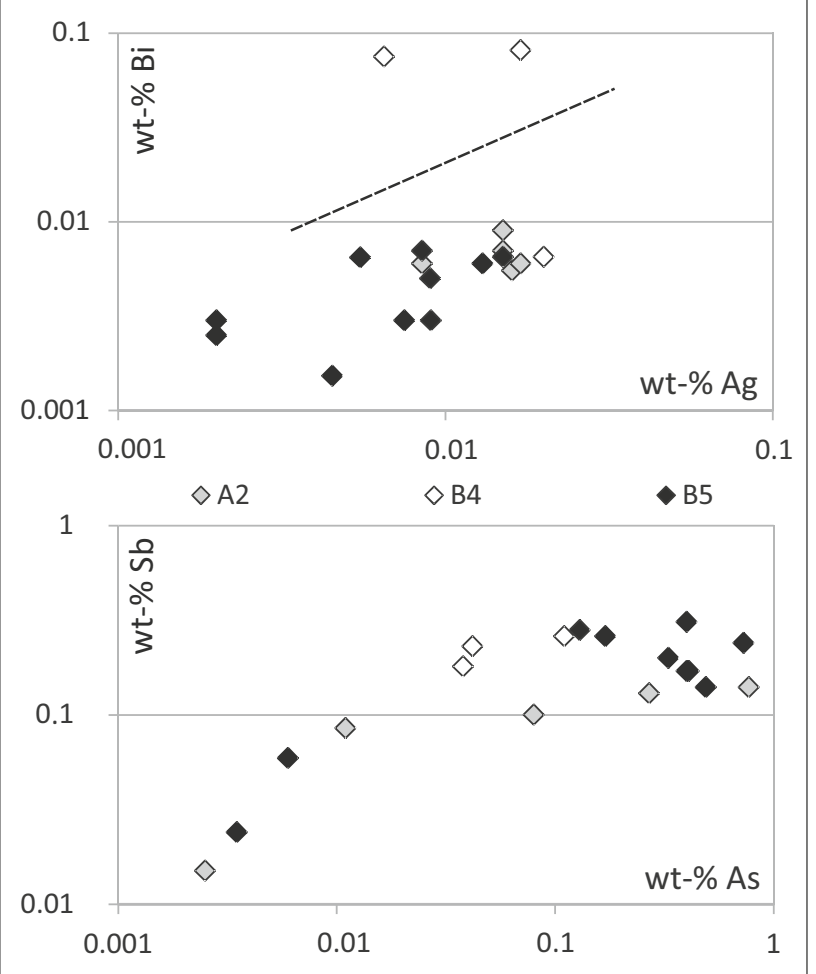

Fig. $7 \mathrm{XY}$-diagrams with $\mathrm{Ag}, \mathrm{As}, \mathrm{Bi}$, and $\mathrm{Sb}$ contents in Comacchio lead ingots of type A2 (grey diamonds), B4 (white diamonds), and B5 (black diamonds) (M. Bode)

hypothetical. Because of the flat-bottomed type of the ship and the proximity of the archaeological site to the mouth of the river Po, it is tempting to assume that the final destination is upstream at the Po or near it (see Lavizzarri Pedrazzini 2010). A further journey to the ports along the north Adriatic coast (especially Aquileia) or instead a journey from these places were also considered (e.g., Rodá 2007; Domergue et al. 2012). A connection with the expansion of the Roman fleet base near Ravenna under Octavian/Augustus in the years 35-12 BC is also conceivable, whereby Agrippa's role remains unclear (compare, e.g., also Domergue et al. 2012). The linear distance between the location of the wreck and the military port is about $40 \mathrm{~km}$.

Furthermore, the role of Agrippa as patronus of various cities in Italy and in the provinces must be pointed out. The ancient city of Claternae (now Maggio d'Ozzano dell'Emilia, pr. Bologna), whose patron according to an inscription was Agrippa, is relatively close (approx. $60 \mathrm{~km}$ linear distance) to the place where the Comacchio shipwreck was found (see Roddaz 1984, 2009).

Another scenario to be taken into account is the Alpine campaign of Drusus maior and Tiberius in 15 BC. In this context, northern Italy is seen as a deployment base and supply area for the Roman troops (Zanier 2010; Nuber 2010). 
But although numerous lead slingshot projectiles from Roman troops came to light at the Roman military camp on the Septimer Pass and at the battlefield in the Crap Ses Gorge in Graubünden (Swiss), they do not match the lead isotope compositions of the ingots from Comacchio. In addition, there are also no other indications among the finds from the wreck that the cargo had a military character.

\section{Conclusions}

The lead isotopic evaluation of 20 lead ingots from the shipwreck of Comacchio made a reinterpretation of the previously published provenance of the lead metal necessary. The large lead-silver districts around Carthago Nova with the two areas around La Unión and Mazarrón (pr. Murcia) and the province of Almeria are clearly ruled out as suppliers of the lead cargo according to lead isotope analysis. Although Agrippa's role as patron and therefore a person of influence of Carthago Nova is undisputed and his participation in the lead exploitation on the Iberian Peninsula can be proven also via an ingot find from Menorca (Rodà 2007; Nicolàs and Rodà, 2007), the lead load from Comacchio in the same way highlights his economic influence in the lead (and silver) production in ancient Macedonia in Augustan time. For the first time, a delivery of lead could be seen to emerge from an eastern Mediterranean region to Italy.

Certainly, this provenance result is not intended to suggest that the Adriatic coastal cities were mainly supplied with lead from the Aegean Sea. Spanish lead ingot loads might also had been shipped around the southern coast of the Italian mainland and across the Adriatic Sea, as individual finds of Iberian-type ingots with Spanish lead ore isotope signatures on the east coast of the Apennine peninsula, in Austria, and Croatia prove (e.g. Domergue et al. 1974; Ramallo Asensio and Berrocal Capparos 1994; Vitri et al. 1994; Picottini et al. 2003; Domergue and Piccottini 2004; Böhm and Weber 2005; Zaccaria 2008). This can also be seen in the transport of food (olive oil, fish sauces, etc.) from the Hispanic provinces of the Iberian Peninsula (Jurišić 2000, 2006).

Acknowledgements Our special thanks go to the staff of the Museo Archeologico Nazionale di Ferrara, Caterina Cornelio and Valentina Guerzoni, who, like Laura Ruffoni (Museo Navale, Comacchio), made it possible for us to investigate and sample the lead ingots of the shipwreck despite the adverse circumstances after the earthquake of May 20, 2012. Julian Hollaender M. A. (Munich/Darmstadt) helped with the documentation of the ingots. The lead ingots are now kept in the Museo civico di Nave romana in Comacchio. The visit could be realized as part of the interdisciplinary research project "Corpus of Roman Lead Ingots," which was supported by the Deutsche Forschungsgemeinschaft. We also like to thank Dr. Frank Hulek (Universität zu Köln) for helpful information about the Pangaion Mountain area and its ancient remains and finally for the helpful critical comments from the reviewers.
Funding Open Access funding enabled and organized by Projekt DEAL. The investigations of the Comacchio ingots in the Museo Archeologico Nazionale di Ferrara and scientific analyses have been part of the project "Historisch-archäologische und naturwissenschaftliche Untersuchungen zur Bleiproduktion im römischen Reich" (20092015), funded by the Deutsche Forschungsgemeinschaft. Working title: Corpus of Roman Lead Ingots (CRLI).

Data availability Not applicable.

Code availability Word 2016, Excel 2016, Corel Draw 12.

\section{Declarations}

Conflict of interest The authors declare no competing interests.

Open Access This article is licensed under a Creative Commons Attribution 4.0 International License, which permits use, sharing, adaptation, distribution and reproduction in any medium or format, as long as you give appropriate credit to the original author(s) and the source, provide a link to the Creative Commons licence, and indicate if changes were made. The images or other third party material in this article are included in the article's Creative Commons licence, unless indicated otherwise in a credit line to the material. If material is not included in the article's Creative Commons licence and your intended use is not permitted by statutory regulation or exceeds the permitted use, you will need to obtain permission directly from the copyright holder. To view a copy of this licence, visit http://creativecommons.org/licenses/by/4.0/.

\section{References}

Albarede F, Blichert-Toft J, Gentelli L, Milot J, Vaxevanopoulos M, Klein S, Westner K, Birch Th, Davis G, de Callataÿ (2020) A miner's perspective on $\mathrm{Pb}$ isotope provenances in the Western and Central Mediterranean. J Archaeol Sci 121:1-14

Arribas A Jr, Tosdal M (1994) Isotopic composition of Pb and S in base and precious metal deposits of the Betic Cordillera, Spain: origin and relationship to other European deposits. Econ Geol 89:1074-1093. https://doi.org/10.2113/gsecongeo.89.5.1074

Baron S, Rico Ch, Antonilos Marín JA (2017) The Cabezo del Pino workshops complex (Sierra Minera de Cartagena-La Unión, Murcia) and the mining activities organization at Carthago Noua at the end of the Roman Republic. Cross-contributions of archaeology and geochemistry. Arch Esp Arqueol 90:147-169. https://doi.org/10.3989/aespa.090.017.007

Bode M, Hanel N, Rothenhöfer P (2017) Bleiisotopie und Provenienzstudien - Neue Forschungen zur römischen Bleiproduktion auf der Iberischen Halbinsel. In: Kemkes M (ed) Römische Großbronzen am UNESCO-Welterbe Limes. Abschlusskolloquium des Forschungsprojektes „Römische Großbronzen am UNESCOWelterbe Limes" am 4./5. Februar 2015 im Limesmuseum Aalen. Beitr zum Welterbe Limes, Band 9. Darmstadt, pp 204-211

Böhm K, Weber E (2005) Annona epigraphica Austriaca 2005. Tyche 20:217-258

Berti F (ed) (1990) Fortuna Maris. La nave romana di Comacchio. Exhibitioncatalogue Comacchio, 28.4. - 31.12.1990, Bologna

Canals A, Cardellach E (1997) Ore lead and Sulphur isotope pattern from the low-temperature veins of the Catalanian Coastal Ranges (NE Spain). Miner Depos 32:243-249. https://doi.org/10.1007/s001260050089

Chalkias St, Vavelidis M, Schmitt-Strecker S, Begemann F (1988) Geologische Interpretation der Blei-Isotopen-Verhältnisse von Erzen der Insel Thasos, der Ägäis und Nordgriechenlands. In: 
Wagner GA, Weisgerber G (eds) Antike Edel- und Buntmetallgewinnung auf Thasos. Der Anschnitt, Beiheft 6. Deutsches Bergbau-Museum Bochum, Bochum, pp59-74

Davies O (1935/reprint 1979) Roman Mines in Europe. Arno Press, Oxford

Dayton JE, Dayton A (1986) Uses and limitations of lead isotopes in archaeology. In: Olin JS, Blackman MJ (eds) Proceedings of the $24^{\text {th }}$ International Archaeometry Symposium. Smithsonian Institution Press, Washington D. C., pp3-41

Domergue C, Laubenheimer-Leenhardt F, Liou B (1974) Les lingots de plomb de L. Carulius Hispallus. Rev archéol Narbonn 7:119-137. https://doi.org/10.3406/ran.1974.964

Domergue C (1987) Les lingots de plomb de l'épave romaine de Valle Ponti (Comacchio). Epigraphica 49:109-175

Domergue C, Piccottini G (2004) Apròs du fragment du lingot de plomb hispanique trouvé au Magdalensberg (Carinthie, Autriche). Note additionnel. Rudolfinum 2003:167-169.

Domergue C, Quarati P, Nesta, A, Trincherini PR (2012) Retour sur les lingots de plomb de Comacchio (Ferrara, Italie) en passant par l'archéométrie et l'épigraphie. In: Orejas A, Rico Ch (eds) Minería y metalurgia antiguas. Visiones y revisiones. Homenaje a Claude Domergue, Collect de la Casa de Velázquez 128. Madrid, pp81-103. Since 2006, a version of this article is available online: http://arxiv.org/ftp/physics/papers/0605/0605044.pdf (last access in $15 / 02 / 2021)$

Domergue C, di Vacri ML, Fernández Izquierdo A, Ferrante M, Nesta A, Nisi S, Quarati P, Rico Ch, Trincherini PR (2016) Les lingots de plomb hispano-romains de Q. Vireius. Quad Prehist i Arqueol de Castelló 34:177-196

Drexhage HJ, Konen H, Ruffing K (2002) Die Wirtschaft des Römischen Reiches (1.-3. Jahrhundert). Eine Einführung. AkademieVerlag, Berlin

Dušanić S (2008) The Valle Ponti lead ingots: Notes on Roman notables' commercial activities in free Illyricum at the beginning of the principate. Starinar 58:107-118. http://www.doiserbia.nb.rs/ Article.aspx?ID=0350-02410858107D

Gale NH (1980) Some Aspects of Lead and Silver Mining in the Aegean. In: Doumas G (ed) Thera and the Aegean World II. Papers and Proceedings of the Second International Scientific Congress, Santorini, Greece, August 1978. Aris and Phillips Ltd., London, pp161-195

Gale NH, Picard O, Barrandon JN (1988) The archaic Thasian silver coinage. In: Wagner GA, Weisgerber G (eds) Antike Edel- und Buntmetallgewinnung auf Thasos. Der Anschnitt, Beiheft 6 . Deutsches Bergbau-Museum Bochum, Bochum, pp212-223

Gale NH, Stos-Gale ZA (1992) Lead Isotope Sudies in the Aegean (The British AcademyProject). Proc Br Acad 77:63-108

García-Bellido MP (1995) Las torres-recinto y la explotación militar del plomo en Extremadura: los lingotes del pecio de Comacchio. Anas 7/8:187-218

García-Bellido MP (1998a) Sellos legionarios en los lingotes de plomo de Comacchio (Ferrara). Epigr 60:9-43

García-Bellido MP (1998b) Legionsstempel aus der Zeit des Agrippa auf hispanischen Bleibarren aus Comacchio (Ferrara). Bonner Jahrbücher 198:1-27

García-Bellido MP (2000) Lingots estampillés en Espagne avec de marques de légions et d'Agrippa. In: Le Bohec Y, Wolff C (eds) Les légions de Rome sous le Haut-Empire II. Actes du Congrès de Lyon (17-19 septembre 1998), Collection du Centre d'Études Romaines et Gallo-Romaines, 20, Université Jean-Moulin Lyon 3, vol 2. De Boccard, Paris, pp 685-698

Gialoglou G, Vavelidis M, Wagner GA (1988) Die antiken BleiSilber-Bergwerke auf Thasos. In: Wagner GA, Weisgerber G (eds) Antike Edel- und Buntmetallgewinnung auf Thasos. Der Anschnitt, Beiheft 6. Deutsches Bergbau-Museum Bochum, Bochum, pp75-87
Hanel N, Rothenhöfer P (2013) The Romans and their lead - tracing innovations in the production, distribution, and secondary processing of an ancient metal. In: Burmeister St, Hansen S, Kunst M, Müller-Scheessel N (eds) Metal matters. Innovative technologies and social change in Prehistory and Antiquity. Menschen - Kulturen - Traditionen 12, Rahden/Westfalen, pp273-282

Hauptmann A, Pernicka E, Weisgerber G (1988) Untersuchungen zur Prozesstechnik und zum Alter der frühen Blei-Silbergewinnung auf Thasos. In: Wagner GA, Weisgerber G (eds) Antike Edelund Buntmetallgewinnung auf Thasos. Der Anschnitt, Beiheft 6. Deutsches Bergbau-Museum Bochum, Bochum, pp88-112

Herschend F (1995) Friends of Trimalchio's: A Study of Spanish Lead Ingots from Three Roman Wrecks. Tor 27:269-310

Hunt Ortiz MA, Estarellas BL, Mateo LP, Simonet BS (2014) Aprovechamiento de recursos cupríferos en la edad del bronce de Menorca: La mina de Sa Mitja Lluna (Illa den Colom). In: Editorial Universidad de Granada y Departamento de Prehistoria y Arqueología de la Universidad de Granada (ed.) Mining Landscapes in the Iberian Peninsula: Metallic Mining in Antiquity. Cuadernos de Prehistoria y Arqueología de la Universidad de Granada 24, pp 85-109. https://doi.org/10.30827/ cpag.v24i0.4089

Lavizzari Pedrazzini MP (2010) L'angulus Venetorum e la produzione della terra sigillatanorditalica decorata a matrice. Rei Cretariae Romanae Fautores 41:211-215

Jurišić M (2000) Ancient Shipwrecks of the Adriatic. Maritime transport during the first and second centuries AD. British Archaeological Reports International Series 828. Archaeopress, Oxford

Jurišić M (2006) The maritime trade of the Roman province. In: Davidson D, Gaffney V, Marin E (eds) Dalmatia. Research in the Roman Province 1970-2001. Papers in honour of J. J. Wilkes. British Archaeological Reports International Series 1576. Archaeopress, Oxford, pp 149-173

Marc JY (2019) Die Stadt Thasos: Organisation und Ressourcen. In: Brunet M, Coulié A, Hamon P, Holtzmann B, Marc JY, Muller A, Picard O (eds) Thasos: Aufstieg und Niedergang einer griechischen Polis. Phillip von Zabern, Darmstadt, pp 33-66

Meier SW (1995) Das Blei in der Antike. Bergbau, Verhüttung, Fernhandel. Dissertation, Universität Zürich

Montero-Ruiz I, Gener M, Renzi M, Hunt M, Rovira S, Santos-Zalduegui JF (2009) Provenance of lead in first Iron Age sites in southern Catalonia (Spain). In: Moreau JF, Auger R, Chabot J, Herzog A (eds) Proceedings ISA 2006. 36th International Symposium on Archaeometry (2-6 may, 2006, Québec city, Canada), Quebec. Cahiers d'archéol du CELAT 25. Sér archéométrie 7. Québec, pp391-398

Müller R, Brey GP, Seitz HM, Klein S (2014) Lead isotope analyses on Late Republican sling bullets. Archaeol Anthropol Sci 7:473-485

Nicolàs JC, Rodà I (2007) Un nuevo lingote de plomo con la marca AGRIP In: Mayer i Olivé M, Baratta G, Guzmán Almagro A (eds) XII Congressus internationalis Epigraphiae graecae et latinae. Provinciae Imperii Romani Inscriptionibus descriptae. (Barcelona, 3-8 Septembris 2002), Institut d'Estudis Catalans (Monografies de la Secció Històrico-Arqueològica) Barcelona 3.-8.9.2002. Barcelona 2007, pp 1017-1020

Nuber HU (2010) Militärische Einsatzstrategien im Alpenfeldzug des Jahres 15 v. Chr. In: Aßkamp R, Esch T (eds) Imperium - Varus und seine Zeit. Beiträge zum internationalen Kolloquium des LWL-Römermuseums am 28. und 29. April 2008 in Münster. VAWKomWestfalen 18. Altertumskommision Westfal, Münster, pp59-71

OXALID (n.d.) Oxford Archaeological Lead Isotope Database [online], $<$ http://oxalid.arch.ox.uk/default.html >, [last access on 02/12/20]

Parjanadze T, Bode M (2017) Roman Silver Objects from the Ancient Kingdom of Kartli (Caucasian Iberia) in Georgia (Mtskheta, 
Dedoplis Gora [Kareli district]) - a Lead Isotope Investigation. Metalla 23/2:39-50

Parker AJ (1992) Ancient Shipwrecks of the Mediterranean and the Roman Provinces. British Archaeological Reports International Series 580. Archaeopress, Oxford

Pernicka E, Bachmann HG (1983) Archäometallurgische Untersuchungen zur antiken Silbergewinnung in Laurion. III. Das Verhalten einiger Spurenelemente beim Abtreiben des Bleis. Erzmetall 36:592-597

Pernicka E, Seeliger TC, Wagner GA, Begemann, F, Schmitt-Strecker S, Eibner C, Öztunali Ö, Baranyi I (1984) Archäometallurgische Untersuchungen in Nordwestanatolien. Jahrbuch des RömischGermanischen Zentralmuseums 31:533-599

Pernicka E (1987) Erzlagerstätten in der Ägäis und ihre Ausbeutung im Altertum. Geochemische Untersuchungen zur Herkunftsbestimmung archäologischer Metallobjekte. Jahrbuch des RömischGermanischen Zentralmuseums Mainz 34:607-714. https://doi. org/10.11588/jrgzm.1987.2.72132

Pernicka E, Begemann F, Schmitt-Strecker S, Wagner GA (1993) Eneolithic and Early Bronze Age Copper Artefacts from the Balkans and their Relation to Serbian Copper Ores. Prähist Z 68:1-54. https://doi.org/10.1515/prhz.1993.68.1.1

Piccottini G, Schroll E, Spindler P (2003) Ein römerzeitlicher Bleibarren vom Magdalensberg. Rudolfinum 2002:153-161

Rafael N, Montero-Ruiz I, Castanyer P, Aquilué X, Armada XL, Belarte MC, Fairén S, Gasull P, Gener M, Graells R, Hunt M, Martin A, Mata JM, Morell N, Pérez A, Pons E, Renzi M, Rovira MC, Rovira S, Santos M, Tremoleda J, Villalba P (2010) New approaches on the archaic trade in the northeastern Iberian Peninsula: Exploitation and circulation of lead and silver. Oxf J Archaeol 29:175-202

Ramallo Asensio SF (1985) La minería Romana en Mazarrón (Murcia). Aspectos Arqueológicos y Geológicos. An Prehist Arqueol 1:49-67

Ramallo Asensio SF, Berrocal Capparos MC (1994) Minería púnica y romana en el sureste peninsular: el foco de Carthago Nova. In: Vaquerizo Gil D (eds) Minería y metalurgía en la España prerromana y romana. Actas de los Seminarios de verano „Fons Mellaria 1992“ (Fuenteovejuna, Córdoba). Córdoba, pp79-146

Rodá I (2007) La figura de Agripa, el ejército y la promoción de las obras públicas en Hispania. Larouco. Rev Annu Antig 4:27-43

Roddaz JM (1984) Marcus Agrippa. Bibl Écoles Fr d'Athèn et de Rome 253. Ecole française de Rome, Rome. doi: https://doi.org/ 10.3406/befar.1984.1220

Roddaz JM (2009) Des Nîmes à Lesbos. Agrippa et le patronage des cités. In: Christol M, Darde D (eds) L'expression du pouvoir au début de l'Empire. Autour de la Maison Carrée à Nîmes. Actes du colloque organisé à l'initiative de la ville de Nîmes et de Musée archéologique. Nîmes, 20.-22.10.2005. Paris, pp53-57

Rothenhöfer P, Bode M (2018) Neue Forschungen zu den Planii und ihren ökonomischen Aktivitäten im republikanischen Hispanien. Madr Mitt 59:343-358. https://orcid.org/0000-0002-5882-1843

Rothenhöfer P, Bode M, Hanel N (forthcoming) Corpus of Roman Lead Ingots. Der Anschnitt, Beiheft, Deutsches BergbauMuseum Bochum (Bochum)

Sayre EV, Joel EC, Blackman MJ, Yener KA, Özbal H (2001) Stable lead isotope studies of Black Sea Anatolian ore sources and related Bronze Age and Phrygian artefacts from nearby archeological sites. Appendix: new Central Taurus ore data. Archaeometry 43:77115

Seeliger, Th, Pernicka E, Wagner GA, Begemann F, SchmidtStrecker S, Eibner C, Öztunali Ö, Baranyi I (1985) Archäometallurgische Untersuchungen in Nord- und Ostanatolien. Jahrbuch des Römisch-Germanischen Zentralmuseums 32:597659
Stos-Gale ZA, Gale NH, Houghten J, Speakman R (1995) Lead isotope data from Isotrace Laboratory, Oxford: Archaeometry data base 1, ores from the western Mediterranean. Archaeometry 37:407-415. https://doi.org/10.1111/j.1475-4754.1995.tb00753.xl

Stos-Gale ZA, Gale NH, Annetts N (1996) Lead isotope data from the Isotrace Laboratory, Oxford: Archaeometry data base 3, Ores from the Aegean, Part 1. Archaeometry 38:381-390. https://doi.org/10. 1111/j.1475-4754.1996.tb00784.x

Trincherini PR, Barbero P, Quarati P, Domergue C, Long L (2001) Where do the lead ingots of the Saintes-Maries-de-la-Mer wreck come from? Archaeology compared with Physics. Archaeometry 43:393-406. https://doi.org/10.1111/1475-4754.00023

Trincherini PR, Domergue C, Manteca I, Nesta A, Quarati P (2009) The identification of lead ingots from the Roman mines of Cartagena (Murcia, Spain): the role of lead isotope analysis. J Rom Archaeol 22:123-145. https://doi.org/10.1017/S104775940 0020626

Unger HJ, Schütz E (1980) Pangaion - Ein Gebirge und sein Bergbau, Mythos und Wirklichkeit. Pangaion 1. Landshut

Unger HJ (1981) Wanderungen im Pangaion. Pangaion 2. Landshut

Unger HJ, Schütz E (1982) Ein Gebirge und sein Bergbau. In: Hänsel B (ed) Südosteuropa zwischen 1600 und 1000 v. Chr. Prähistorische Archäologie in Südosteuropa 1. Moreland Aditions -Bad Bramstedt, pp145-172

Unger HJ (1987) Das Pangaion: Ein altes Bergbauzentrum in Ostmakedonien. Prähist Z 62:87-112

Vavelidis M, Bassiakos I, Begemann F, Patriar-Cheas K, Pernicka E, Schmitt-Strecker S, Wagner GA (1985) Geologie und Erzvorkommen der Insel Sifnos. In: Wagner GA, Weisgerber G (eds) Blei, Silber und Gold auf Sifnos. Prähistorische und antike Metallproduktion. Der Anschnitt, Beiheft 3. Deutsches BergbauMuseum Bochum, Bochum, pp 59-80

Vavelidis M, Christophides G, Melfos V (1996) The AuAg-bearing mineralization and placer gold of Palea Kavala (Macedonia, N. Greece). In: Knezevic V, Krstic B (eds) Terraines of Serbia. Faculty of Mining and Geology \& Committee for Geodynamics of Serbian Academy of Science and Art. Belgrad, pp 311-316

Vavelidis M, Christophides G, Melfos V (1997) Ancient gold mines near Krinides in Philippi area (Macedonia, N. Greece). In: Archaeometrie und Denkmalpflege, Kurzberichte. Zusammenfassung der Vorträge und Poster der Gemeinschaftstagung der Arbeitskreise "Archäometrie" der Gesellschaft Deutscher Chemiker und "Archäometrie und Denkmalpflege" der Deutschen Mineralogischen Gesellschaft im Archäologiezentrum der Universität Wien 24.-26. März 1997. Wien, pp 84-86

Veselinovíc-Williams M (2011) Characteristics and Origin of Polymetallic Mineralization in the Kopaonik Region of Serbia and Kosovo, with Particular Reference to the Belo Brdo Pb-Zn (Ag) Deposit. Dissertation, Kingston University London

Vitri S, Gomezel C, Prenc F (1994) Un lingotto di piombo dal Fiume Stella. Aquileia Nostra 65:290-291

Wagner GA, Pernicka E, Vavelidis M, Baranyi I, Bassiakos I (1986) Archäometallurgische Untersuchungen auf Chalkidiki. Der Anschnitt 38, Heft 5-6. Deutsches Bergbau-Museum Bochum, Bochum, pp66-186

Wagner GA, Wagner I, Öztunali Ö, Schmidt-Strecker S, Begemann F (2003) Archäometallurgischer Bericht über Feldforschung in Anatolien und bleiisotopische Studien an Erzen und Schlacken. Der Anschnitt, Beiheft 16. Deutsches BergbauMuseum Bochum, Bochum, pp475-494 
Westner K (2017) Roman Mining and Metal Production near the Antique City of ULPIANA (Kosovo). Dissertation, GoetheUniversität Frankfurt am Main

Zaccaria C (2008) Instrumenta inscripta Latina: potenziale informative e importanza dei corpora elettronici. Alcuni esempi dalla Regio X orientale. In: Hainzmann M, Wedenig R (eds) Instrumenta Inscripta Latina 2. Akten 2. Internationalen Kolloquiums Klagenfurt 2005. Aus Forsch und Kunst 36. Geschichtsverein für Kärnten, Klagenfurt, pp361-362
Zanier W (2010) Der römische Alpenfeldzug unter Tiberius und Drusus im Jahre 15 v. Chr. Übersicht zu den historischen und archäologischen Quellen. In: Aßkamp R, Esch T (eds) Imperium - Varus und seine Zeit. Beiträge zum internationalen Kolloquium des LWLRömermuseums am 28 und 29. April 2008 in Münster. Veröffentlichungen der Altertumskomm Westfal 18, Münster, pp73-96

Publisher's note Springer Nature remains neutral with regard to jurisdictional claims in published maps and institutional affiliations. 